Corruption in cyclone preparedness and relief efforts in coastal Bangladesh lessons for climate adaptation?

Mahmud, Tanvir; Prowse, Martin

Published in:

Global Environmental Change

DOI:

10.1016/j.gloenvcha.2012.07.003

Publication date:

2012

Document version

Peer reviewed version

Citation for published version (APA):

Mahmud, T., \& Prowse, M. (2012). Corruption in cyclone preparedness and relief efforts in coastal Bangladesh: lessons for climate adaptation? Global Environmental Change, 22(4), 933-943.

https://doi.org/10.1016/j.gloenvcha.2012.07.003 


\title{
Corruption in cyclone preparedness and relief efforts in coastal Bangladesh: Lessons for climate adaptation?
}

\author{
Tanvir Mahmud ${ }^{\mathrm{a}}$, Martin Prowse ${ }^{\mathrm{b}, *}$ \\ ${ }^{a}$ Transparency International Bangladesh, H. No. 141, R. No. 12, Block E, Banani, Dhaka 1213, Bangladesh \\ ${ }^{\mathrm{b}}$ Institute of Development Policy and Management (IOB), University of Antwerp, Lange St. Annastraat 7, B-2000 Antwerp, Belgium
}

\section{A R T I C L E I N F O}

\section{Article history:}

Received 21 April 2011

Received in revised form 26 June 2012

Accepted 7 July 2012

Available online 31 July 2012

\section{Keywords:}

Corruption

Adaptation

Bangladesh

\begin{abstract}
A B S T R A C T
This article seeks to draw possible lessons for adaptation programmes in Bangladesh by examining whether cyclone preparedness and relief interventions are subject to corrupt practices. Based on a random sample survey of 278 households, three focus-group discussions and seven key-informant interviews, the article investigates the nature and extent of corruption in pre- and post-disaster interventions in Khulna before and after Cyclone Aila in May 2009. Ninety nine percent of households reported losses from corrupt practices. Post-disaster interventions (such as food aid and public works schemes) suffered from greater levels, and worse types, of corruption than pre-disaster interventions (such as cyclone warning systems and disaster-preparedness training). Using an asset index created using principal component analysis, the article assesses how corruption affected wealth quartiles. Ultrapoor households were affected more by corruption in pre-disaster interventions, the wealthiest quartile more in certain post-disaster interventions, in particular public works and non-governmental interventions. These findings may hold lessons for attempts to increase resilience as current adaptation measures mirror some cyclone preparedness and relief efforts.
\end{abstract}

(c) 2012 Elsevier Ltd. All rights reserved.

\section{Introduction}

The Intergovernmental Panel on Climate Change (2001, 2007) indicates Bangladesh is highly vulnerable to climate change. Projected impacts include greater scarcity of fresh water in the dry season (due to less rain and higher evapotranspiration), greater drainage congestion (due to higher levels in water courses partly from higher sea levels), greater river bank erosion, more frequent and severe floods and cyclones, and greater soil salinity in the coastal zone. Such hydrological changes particularly threaten lowlying coastal areas where citizens live in flood- and cyclone-prone locations.

The Bangladeshi government is committed to adaptation as illustrated by the country's National Adaptation Programme of Action (NAPA), the Climate Change Strategy and Action Plan, National Climate Change Trust Fund and the multi-donor Climate Resilient Fund (for example, see MoEF, 2005, 2009, and GLCA, 2009). However, the success of programmes depends partly on the

\footnotetext{
* Corresponding author. Current address: Department of Geography and Geology, University of Copenhagen, Øster Voldgade 10, 1350 Copenhagen, Denmark. Tel.: +453532 2500 .

E-mail addresses: martin.prowse@geo.ku.dk, prowsemartin@hotmail.com (M. Prowse).
}

level of fiduciary risk (in other words, that adaptation funds are used for intended purposes). Here there is good reason to be concerned. Bangladesh was ranked bottom of Transparency International's Corruption Perceptions Index (CPI) for five consecutive years between 2001 and 2005. Whilst this ranking has recently recently, the $2010 \mathrm{CPI}$ still placed Bangladesh 134th from 178 countries.

To try and draw useful lessons for climate adaptation, this article investigates the nature and extent of corruption in cyclone preparedness and relief efforts in coastal Bangladesh. It focuses on interventions before and after Cyclone Aila that struck South-West Bangladesh and coast of West Bengal, India, on the 25th May, 2009. According to the Disaster Management Bureau (2010), Aila killed 190 people directly and affected over 3.9 million (with 243,000 houses and 77,000 acres of farmland destroyed or badly damaged). Even fourteen months afterwards, when the primary research for this article was conducted, embankments in four upazillas (the sub-district administrative unit) in Khulna and Satkhira districts had not been repaired and over 47,000 households were still homeless. A key aim of the research was to investigate how the experience of corruption varied across wealth groups.

The article consists of five further sections. Section Two offers a quick overview of the relationship between corruption and development, a brief summary of the emergent literature on corruption and climate change, before focusing on corruption in 
Bangladesh. The third section discusses the inherent difficulties of researching corruption, and outlines the research methods and statistical techniques employed. Sections 4 and 5 present findings on corruption in pre- and post-disaster interventions, respectively. The sixth section concludes.

\section{Corruption in Bangladesh: an overview}

The extent to which corruption impedes national development has been a matter of debate. The intuitive argument that corruption is one cause of low economic growth and high poverty rates (Myrdal, 1968) can be contrasted against arguments where corruption is seen to improve efficiency through overcoming market failures caused by bureaucracies (Leff, 1964). The recent macro-level evidence, unsurprisingly, favours the former argument, especially when considering human development, and highlights multiple equilibria in the negative relationship between corruption and development (see Aidt, 2009; Haque and Kneller, 2009; Qizilbash, 2001). Numerous micro-level mechanisms - such as path dependency through reduced reporting, lower penalities and peer-group effects - are suggested as possible channels through which countries remain locked in a high corruption, low development trap (see Aidt, 2009).

Despite substantial financial flows required for mitigation and adaptation, until recently there has been little mention of corruption within climate debates. This can partly be explained by the burden of mitigation falling on Annex I parties where, on the whole, there are reasonably low levels of corruption, and the late arrival of adaptation to the climate stage (Pielke et al., 2007). However, due partly to a lack of integrity within the Clean Development Mechanism (Green, 2008; Ostrom, 2010), concerns about high levels of corruption in certain forestry ministries (see Ebeling and Yasue, 2009; Barr et al., 2010) and the pressing need to disburse fast-start funding for adaptation, greater emphasis is now being placed on corruption. This is most clearly demonstrated through Transparency International's (2011) annual report on climate change. This includes two chapters on Bangladesh Martinez and Bastemeijer (2011) and Zaman and Khuda (2011) where it is accepted corruption is widespread and contributes to social and economic deprivation (Iftekharuzzaman, 2009; Iftekharuzzaman and Tanvir, 2008; TIB, 2008; Tanvir, 2006). For example, the World Bank (2000) estimated if Bangladesh could reduce corruption to the level prevailing in Scandinavian countries, it could add 2.1 to 2.9 percent to annual per capita GDP growth.

Whilst corruption is often defined as the abuse of public office for private gain' (see Bardhan, 1997), this article uses Transparency International's definition of corruption - the abuse of entrusted power for private gain - and considers eight forms of corruption (see Transparency International, 2009; Karklins, 2002). First, bribery, defined as offering, promising, giving, accepting or soliciting an advantage as an inducement for an action which is illegal, unethical or a breach of trust. Second, wage/asset stripping, which is the appropriation or illegal use of entrusted funds/goods for personal gain. Third, extortion, defined as an act of utilizing, either directly or indirectly, one's access to a position of power or knowledge to coerce unmerited cooperation or compensation. For example, a service provider may force a recipient to make an unofficial payment. Fourth, fraud, the act of intentionally deceiving someone in order to gain unfair or illegal advantage. Fifth, favouritism, nepotism and patronage. Usually based on acquaintances and kin relations, these actions involve the exploitation of power/authority to provide unmerited opportunities for family or friends. Patronage often seeks the cultivation of political and/or clientelist networks. Sixth, refusal or negligence to provide services. For instance, when service providers create a barrier so recipients offer illicit payments. Seventh, influence peddling, defined as influencing decision-making for personal benefit (and which contrasts with legitimate political lobbying). And eighth, procurement irregularities, where an official awards a contract or influences the tendering process for personal interest.

Transparency International Bangladesh (2010) provides estimates of the scale of corruption: $72 \%$ of households were forced to pay bribes averaging Tk. 4834 (US\$ 68.6) for receiving services from different sectors from June 2009 to May 2010. This equates to a mean annual per capita figure of Tk. 637 (US\$ 9.04), and a total of Tk. 95.92 billion (US\$ 1.36 billion). The same survey shows the incidence of corruption was highest in the judiciary (where $88 \%$ of households receiving services were victims of corruption), followed by the law enforcement services (80\%) and land administration (71\%), as illustrated in Table 1.

Importantly, the impact of corruption differs across wealth categories. Iftekharuzzaman (2009) estimates that $3.84 \%$ of annual household income in 2007 was absorbed by corruption in six sectors (education, health, land administration, law enforcement, the judiciary and tax authorities). Disaggregated by income categories, these estimates suggest low-income households lost 4.1 percent, middle-income households 3.6 percent, and highincome households 2.4 percent of annual income.

There is also evidence some sectors central to climate policy and adaptation - for example, forest and environment, and disaster management and relief - suffer from corrupt practices. TIB's Corruption Database 2005, which utilises and verifies reports of corruption published in leading newspapers, suggests forest and environment was one of the most corrupt sectors in Bangladeshi society. Almost $90 \%$ of individuals reportedly involved in corrupt practices in this sector were government officers/employees, with

Table 1

Extent of corruption in Bangladesh's service sectors, June 2009-May 2010.

\begin{tabular}{|c|c|c|c|c|}
\hline Sector & $\begin{array}{l}\text { Proportion of households } \\
\text { receiving services who } \\
\text { experienced corruption (\%) }\end{array}$ & $\begin{array}{l}\text { Proportion of households } \\
\text { receiving services who } \\
\text { paid bribes (\%) }\end{array}$ & $\begin{array}{l}\text { Average amount } \\
\text { of bribe paid } \\
\text { (in Taka) }\end{array}$ & $\begin{array}{l}\text { National estimate } \\
\text { of bribes paid } \\
\text { (in millions of Taka) }\end{array}$ \\
\hline Judiciary & 88.0 & 59.6 & 7918 & 16192 \\
\hline Law enforcement agencies & 79.7 & 68.1 & 3352 & 5014 \\
\hline Land administration & 71.2 & 67.0 & 6116 & 35194 \\
\hline Tax, VAT \& customs & 51.3 & 43.9 & 6734 & 2235 \\
\hline Electricity & 45.9 & 27.6 & 1834 & 8126 \\
\hline Local government & 43.9 & 36.7 & 913 & 6283 \\
\hline Health & 33.2 & 13.2 & 463 & 1691 \\
\hline Banking & 17.4 & 12.7 & 1928 & 3927 \\
\hline Education & 15.3 & 15.0 & 168 & 1087 \\
\hline NGO & 10.1 & 7.2 & 549 & 422 \\
\hline Others & 34.1 & 35.5 & 6804 & 11570 \\
\hline Overall & 84.2 & 71.9 & 4834 & 95916 \\
\hline
\end{tabular}


$62 \%$ of reported cases involving the abuse of power (a composite term encapsulating extortion, favouritism/nepotism/patronage, influence peddling, and procurement irregularities), followed by bribery (22\%) and asset stripping ( $8 \%$ ). The database also suggests the disaster management and relief sector suffered from lower levels of corruption. In this sector, $91 \%$ of individuals allegedly involved in corruption were elected representatives with $54 \%$ of alleged cases involving the abuse of power and $37 \%$ bribery. Before reporting our findings on corruption in pre- and post-disaster interventions associated with Cyclone Aila, we discuss the intrinsic difficulties of generating accurate data on corruption, and the research methods and statistical techniques employed.

\section{Researching corruption, methods and statistical techniques}

Measuring corruption is very challenging. Not only is it a 'hidden' phenomenon, but corrupt practices are manifestations of broader systemic failures which condition actors' behaviour (Duncan and Dutta, 2006). In this respect, abstracting isolated incidents of corruption from wider processes risks misunderstanding its impact (ibid.). That said, certain research approaches can improve the likelihood of accurately measuring and understanding the phenomenon. For example, Reinikka and Svensson (2006) detail how precise definitions, triangulation with qualitative methods and formal hypothesis testing can improve the data generated (on this last point, see Olken, 2007, for an innovative experimental approach). Our approach in this article - to elicit information from beneficiaries of pre- and post-disaster interventions - resonates strongly with the first two of these 'principles'.

In this respect, we explicitly differentiate the nature of corruption we investigated, and clearly state whether data is first or second hand. In what follows, the extent of corruption is measured by both its frequency (the proportion of beneficiaries affected, or who claim corruption took place) and its severity. There are two aspects to the severity of each practice. First, the income/opportunities lost as a consequence of corrupt practices. This is detailed where possible. Second, the vulnerability of victims. Because corruption in pre-disaster interventions took place before households' vulnerability was exacerbated by Cyclone Aila such practices have been allocated a 'mild' rating. In other words, perpetrators were not certain their actions would harm (for they were not fully aware of the imminent risk). In contrast, corrupt practices in post-disaster interventions have been allocated a 'severe' rating as such practices occurred after households were in acute distress. In other words, perpetrators were fully aware their actions would harm (and as such were especially callous). We also need to be clear about first- and second-hand accounts of corruption. Needless to say, only data about respondents' own experience of corruption can be treated as robust. The only occasion we utilise second-hand hearsay data is regarding government attempts to reconstruct embankments (and the reader is advised to be cautious about these results).

Fieldwork was conducted in collaboration with the Coastal Research Foundation (CRF) during June/July 2010. A household survey, focus group discussions (FGDs) and key informant interviews (KIIs) were conducted. It should be noted the study area is remote with little infrastructure or law and order. Before entering the field it was essential to develop a good network with law enforcement agencies and elites to ensure the security of the research team. Unsurprisingly in such a context, some respondents were nervous or were interrupted by friends or family members during the interview. These questionnaires were excluded from the analysis.

The survey was conducted in one upazilla in Khulna, due to the severe impact of Aila on this part of the coastal belt. A three-stage random sampling technique was followed: one union was randomly selected from the upazilla; four wards were randomly selected from the union; and 75 households were randomly selected from each ward. As a sampling frame was not available in this post-disaster setting, we utilized a transect approach. Depending on the population size in the ward, every fifth to ninth household was selected. The study aimed to sample 300 households, but during data cleaning 22 questionnaires were excluded as the veracity of responses was questionable. Eight experienced assistants were recruited and trained for the survey. Each enumerator surveyed six to seven households per day. Questionnaires were checked each evening by the lead researcher and unsuitable questionnaires returned. In cases where the household head was not available, subsequent visits were made. If the household head was still not available, an adult decision maker was interviewed.

Survey data was triangulated with three focus group discussions conducted with different community groups: women, the social elite (school teachers, religious leaders, public officers, and businessmen), and farmers/day labourers (averaging ten participants). Seven key informant interviews were also conducted during and after the survey to assess corruption in disaster management. Informants included the Member of Parliament, chairmen of upazilla parishad and union parishad, government officers, a representative from a civil society organisation, and journalists. Semi-structured checklists were used during both FGDs and KIIs.

To enable the comparison of corruption across wealth categories, we utilised an asset index. Different authors suggest various methods and techniques to construct such indices (for example, see Filmer and Pritchett, 2001; Hulme and McKay, 2005; Moser and Felton, 2007), and they are being utilised with increasing frequency (see, for example, Ansoms and McKay, 2010; Dasgupta and Baschierri, 2010; Marivoet and Keje, 2011). A recent overview of applications is offered by Harttgen and Klasen (2012) who argue asset indices can be seen as robust proxies for income/expenditure data (but not consumption data, see Howe et al., 2009). As such, they argue whilst asset indices are not perfect proxies they provide a good indicator of long-term living standards.

We utilised principal components analysis (PCA), a data reduction technique to summarise an original set of variables to a set of uncorrelated components. Such an approach offers a straightforward and parsimonious way of assessing wealth, and arguably vulnerability and adaptive capacity (see Adger et al., 2004; Rygel et al., 2006). Our sample size of 278 households is sufficient for PCA (Tabachnick and Fidell, 2007). We used the Sustainable Rural Livelihoods framework as a guiding tool (Chambers and Conway, 1992; Carney, 1999). Under this framework five types of capital assets are distinguished: human capital, socio-political capital; natural capital; physical capital; and financial capital. Under these five capitals, we used 17 variables from reported data on asset holdings before Aila:

- Human capital: years of education of household head.

- Social/political capital: social and political connections of households (whether they take part in salish - a social system for informal arbitration of petty disputes; are a member of a school management/religious committee; or have relatives among government officers, journalists, or public representatives).

- Natural capital: total cultivatable land (acres).

- Physical capital: type of housing structure and ownership of consumer durables/capital goods (TV, radio, bike, pots, table and chairs, mobile phone).

- Financial capital: average monthly household income.

Second, the variables within physical capital and socio-political capital were aggregated using nominal weights: monetary value for the former (apart from housing which also accrued a nonmonetary value); authors' expertise for the latter. Third, we 
ensured the five capitals were normally distributed and significantly correlated at the $99 \%$ level. Fourth, appropriate robustness checks were utilised to ensure data was suitable for Principal Components Analysis. The Kaiser-Meyer-Olkin Measure of Sampling Adequacy tested for the proportion of variance in the variables caused by underlying processes. The result of 0.74 is well within the necessary range for PCA $(>0.5$ and $<1)$. The data also satisfied the Bartlett's Test of Sphericity (Approximate Chi-Square 251.968; d.f. 10; Sig. 0.000) which tested the hypothesis the correlations in the correlation matrix are zero (but which is very sensitive to sample size - see Tabachnick and Fidell, 2007).

As Table 2 shows, PCA extracted one component from the five capitals with the necessary eigenvalue of greater than 1 (again, see Tabachnick and Fidell, 2007). This component explained $47 \%$ of the variance in the original variables. The component score coefficients show the factor loadings applied to the five variables to construct the asset index (human capital 0.257 , natural capital 0.287 , sociopolitical capital 0.263 , financial capital score 0.31 , physical capital score 0.338 ). Fifth, the asset score was sorted in an ascending fashion and used to divide the households into four equally-sized wealth quartiles: ultra poor, poor, a middle group and the wealthy. We now turn to our findings, first on corruption in pre-disaster interventions.

\section{Corruption in pre-disaster Interventions}

Three pre-disaster interventions are now discussed: cyclone warning systems; disaster-preparedness training; and access to cyclone shelters. Each part assesses access to these services across the four wealth quartiles.

\subsection{Cyclone warning systems}

The survey found only $38 \%$ of households received a warning message before Aila (see Table 3). Looking into the wealth quartiles, a higher proportion of wealthy households received a message (55\%) compared to poorer households (significant at the $99 \%$ level). For example, only $24 \%$ of ultra-poor households received one. Table 3 also shows households' perception of the suitability of warning messages before Aila, with $83 \%$ not considering messages as 'appropriate'. Looking into poverty quartiles, $93 \%$ of ultra-poor households through to $72 \%$ of wealthy households considered the messages as 'inappropriate' (significant at the $99 \%$ level). The survey also enquired about the different ways warning messages were received by households (see Table 4). Here, the difference between wealth groups is not substantial. For example, most of the poorest (46.7\%) and wealthiest households (54.3\%) received warning messages by radio or television, from the market place or from friends/relatives.

That many households did not receive a warning message poses questions about the effectiveness of early warning systems. Specifically, it suggests a negligence to provide services. Bangladesh has a good administrative set-up within local government. Along with the Weather Forecast Department and Disaster Management Committee at the local level, the union parishad (lower tier of local government) is responsible for the dissemination of warning messages by different means (including a microphone announcement). It appears many of these systems failed.

In addition, although $38 \%$ of households received a cyclone warning before Aila, they did not take it seriously enough. Participants in two FGDs explained as the height of the previous tidal surge during Cyclone Sidr in 2007 was over-estimated, many people under-estimated the height during Aila. In addition, Aila was only given a category 7 cyclone rating. As people in this upazilla are used to facing more serious threats, they did not give the warning message sufficient credence. Respondents also suggested businessmen, with the help of Water Development Board officials, had weakened the strength of embankments through cutting holes so saline water could allow shrimp cultivation. A high tidal surge, excessive water pressure and poor maintenance meant "everything was destroyed within a single moment. Many people were washed away with the tidal surge, others were helpless struggling to survive".

\subsection{Disaster preparedness training}

We now consider whether households attended disaster preparedness training before or after Aila. Table 5 shows only $14 \%$ of households attended a training session beforehand. This is a

Table 2

Total variance explained: principal component analysis.

\begin{tabular}{|c|c|c|c|c|c|c|}
\hline \multirow[t]{2}{*}{ Component } & \multicolumn{3}{|c|}{ Initial eigen values } & \multicolumn{3}{|c|}{ Extraction sums of squared loadings } \\
\hline & Total & $\%$ of variance & Cumulative \% & Total & $\%$ of variance & Cumulative \% \\
\hline 1 & 2.337 & 46.736 & 46.736 & 2.37 & 46.736 & 46.736 \\
\hline 2 & .945 & 18.895 & 65.632 & & & \\
\hline 3 & .688 & 13.755 & 79.387 & & & \\
\hline 4 & .566 & 11.317 & 90.704 & & & \\
\hline 5 & .465 & 9.296 & 100.000 & & & \\
\hline
\end{tabular}

Source: Authors' calculations.

Extraction method: principal component analysis.

Table 3

- Warning message before Aila by wealth quartiles.

\begin{tabular}{|c|c|c|c|c|c|c|}
\hline \multirow[t]{2}{*}{ Poverty Quartiles } & \multicolumn{3}{|c|}{ Received warning message (\%) } & \multicolumn{3}{|c|}{ Appropriateness of Aila message (\%) } \\
\hline & Yes & No & Total & Yes & No & Total \\
\hline Ultra Poor & 24.3 & 75.7 & 100 & 7.2 & 92.8 & 100 \\
\hline Poor & 44.3 & 55.7 & 100 & 20.3 & 79.7 & 100 \\
\hline Middle & 29 & 71 & 100 & 11.6 & 88.4 & 100 \\
\hline Wealthy & 55.1 & 49.9 & 100 & 27.5 & 72.5 & 100 \\
\hline \multirow[t]{2}{*}{ Total } & 38.1 & 61.9 & 100 & 16.7 & 83.3 & 100 \\
\hline & \multicolumn{3}{|c|}{$\alpha=0.01$, d.f $=3, \chi^{2}=17.65$} & \multicolumn{3}{|c|}{$\alpha=0.007$, d.f $=3, \chi^{2}=12.209$} \\
\hline
\end{tabular}


Table 4

Medium of warning message by wealth quartiles.

\begin{tabular}{|c|c|c|c|c|}
\hline \multirow[t]{2}{*}{ Wealth category (\%) } & \multicolumn{4}{|l|}{ Warning Message Received from } \\
\hline & Market or friends or relatives & Radio or television & Mike announcement or mobile text message & Total \\
\hline Ultra poor & $45 \%$ & $45 \%$ & $10 \%$ & $100 \%$ \\
\hline Poor & $39.5 \%$ & $50 \%$ & $10.5 \%$ & $100 \%$ \\
\hline Middle & $28.6 \%$ & $61.9 \%$ & $9.5 \%$ & $100 \%$ \\
\hline Wealthy & $31.9 \%$ & $51.1 \%$ & $17 \%$ & $100 \%$ \\
\hline
\end{tabular}

Source: household survey, based on multiple responses.

Table 5

- Disaster preparedness training program before and after Aila.

\begin{tabular}{|c|c|c|c|c|c|c|c|c|c|c|}
\hline \multirow[t]{2}{*}{ Wealth quartiles } & \multicolumn{3}{|c|}{$\begin{array}{l}\text { Disaster preparedness training/ } \\
\text { program before Aila (\%) }\end{array}$} & \multicolumn{3}{|c|}{$\begin{array}{l}\text { Disaster preparedness training/ } \\
\text { program after Aila (\%) }\end{array}$} & \multicolumn{4}{|c|}{ Irregularities in training program (\%) } \\
\hline & Yes & No & Total & Yes & No & Total & Yes & No & No response & Total \\
\hline Ultra poor & 10 & 90 & 100 & 21.4 & 78.6 & 100 & 22.9 & 35.7 & 41.4 & 100 \\
\hline Poor & 17.1 & 82.9 & 100 & 12.9 & 87.1 & 100 & 35.7 & 28.6 & 35.7 & 100 \\
\hline Middle & 8.7 & 91.3 & 100 & 17.4 & 82.6 & 100 & 40.6 & 24.6 & 34.8 & 100 \\
\hline Wealthy & 21.7 & 78.3 & 100 & 29 & 71 & 100 & 24.6 & 44.9 & 30.4 & 100 \\
\hline \multirow[t]{2}{*}{ Total } & 14.4 & 85.6 & 100 & 20.1 & 79.9 & 100 & 30.9 & 33.5 & 35.6 & 100 \\
\hline & \multicolumn{3}{|c|}{$\alpha=0.095$, d.f $=3, \chi^{2}=6.367$} & \multicolumn{3}{|c|}{$\alpha=0.109$, d.f $=3, \chi^{2}=6.061$} & \multicolumn{4}{|c|}{ Substantial proportion of non responses } \\
\hline
\end{tabular}

Source: Household survey.

surprisingly low figure for such a hazard-prone location. Again, looking into wealth quartiles, the greatest proportion is the $22 \%$ of wealthy households. Middle strata households (9\%) attended less than both poor (17\%) and ultra-poor households (10\%) (the chisquared statistic reports significance at the $90 \%$ level of confidence).

Table 5 also displays a slightly different picture regarding participation in training after Aila. Overall, $80 \%$ of households did not attend any training after the cyclone. Again, a greater proportion of wealthy households (29\%) managed to attend, this time followed by the ultra poor $(21 \%)$, middle households $(17 \%)$ and poor households (13\%) but these differences are not statistically significant $\left(\chi^{2}=6.061,3\right.$ degrees of freedom, $(=0.109)$. In addition, Table 5 illustrates the nature of irregularities in disaster preparedness training (based on those attending training sessions). It shows $31 \%$ of these households observed irregularities, particularly middle $(41 \%)$ and poor households (35.7\%). The most prominent irregularity was nepotism and the same people attending training sessions (Table 6).

\subsection{Access to cyclone shelters}

The survey enquired about respondents' access to cyclone shelters. Table 7 shows the types of shelter used by households during Aila: $58 \%$ took shelter on an embankment or at home and $32 \%$ in a union parishad/school/or other concrete building. Importantly, only $10 \%$ accessed a cyclone shelter, varying from

Table 6

Types of irregularity in disaster preparedness training program by wealth quartiles.

\begin{tabular}{llll}
\hline Wealth quartiles & \multicolumn{2}{l}{$\begin{array}{l}\text { Types of irregularities in training } \\
\text { program (\%) }\end{array}$} & Total \\
\cline { 2 - 3 } & $\begin{array}{l}\text { Nepotism/same } \\
\text { people attended } \\
\text { various training }\end{array}$ & $\begin{array}{l}\text { Trainee selection } \\
\text { based on political } \\
\text { considerations }\end{array}$ & \\
& 57.1 & 42.9 & 100 \\
\hline Ultra poor & 71.9 & 28.1 & 100 \\
Poor & 67.7 & 32.3 & 100 \\
Middle group & 57.1 & 42.9 & 100 \\
Wealthiest & &
\end{tabular}

Source: Household survey, based on multiple responses.
$4.3 \%$ of ultra-poor households to $13 \%$ of wealthy households (these differences are not statistically significant). Table 7 also shows $31 \%$ were refused access to shelters with the greatest proportions coming from middle (38\%) and poor (32\%) households (again, these differences are not statistically significant).

Furthermore, the table highlights reasons for the lack of access to shelters. It shows $50 \%$ of responses pinpointed space constraints, and $41 \%$ referred to households not having enough time to reach shelters (which raises questions regarding the timing of early warning systems, as well as the location of shelters - on these points see Vogt et al., 2009). Only 9\% of responses from households claimed space was reserved by the elite (although, interestingly, $25 \%$ of the ultra poor thought so).

Data from focus groups support these findings. For example, one participant from the women's group explained: "due to space constraints many people did not get in a cyclone shelter. as they were far away from their house, or they previously had a bad experience. Most of the people were forced to take shelter on the embankment though it was not safe". Overall, and despite the widespread negligence to provide warning messages about Aila, we find a relatively low level of 'mild' corruption in pre-disaster interventions compared to post-disaster relief interventions, to which we now turn.

\section{Corruption in post-disaster relief interventions}

Post-disaster relief interventions are particularly prone to corruption because of the swift, substantial flow of resources required to meet the pressing needs of affected households. Such relief programmes are sequential. First, short- and long-term recovery interventions bring immediate relief to affected households. Later, rehabilitation interventions, such as grants for house rebuilding and embankment reconstruction provide longer-term assistance. We discuss a number of interventions under each category. The first part focuses on post-disaster recovery interventions, the second rehabilitation interventions. Moreover, we discuss three types of government recovery schemes: first, emergency recovery relief (where households received Tk. 3000-5000); second, one medium-term relief intervention (where households received $20 \mathrm{~kg}$ of rice each month); and third, 
Table 7

Access to types of shelter during Aila.

\begin{tabular}{|c|c|c|c|c|c|c|c|c|c|c|c|}
\hline \multirow[t]{2}{*}{ Wealth quartiles } & \multicolumn{4}{|c|}{ Shelter taken during Aila (\%) } & \multicolumn{3}{|c|}{$\begin{array}{l}\text { Refused access to } \\
\text { cyclone shelter (\%) }\end{array}$} & \multicolumn{4}{|c|}{$\begin{array}{l}\text { Reasons for lack of access to cyclone } \\
\text { shelter (\%)* }\end{array}$} \\
\hline & $\begin{array}{l}\text { Cyclone } \\
\text { shelter }\end{array}$ & $\begin{array}{l}\text { Union parishad/school/ } \\
\text { other concrete building }\end{array}$ & $\begin{array}{l}\text { Embankment/ } \\
\text { at home }\end{array}$ & Total & Yes & No & Total & $\begin{array}{l}\text { Reserved by } \\
\text { social elite }\end{array}$ & $\begin{array}{l}\text { No } \\
\text { space }\end{array}$ & $\begin{array}{l}\text { Not enough } \\
\text { time to/other }\end{array}$ & Total \\
\hline Ultra poor & 4.3 & 25.7 & 70 & 100 & 25 & 75 & 100 & 25 & 33.3 & 41.7 & 100 \\
\hline Poor & 10 & 38.6 & 51.4 & 100 & 32.1 & 67.9 & 100 & 12 & 52 & 36 & 100 \\
\hline Middle & 13 & 30.4 & 56.5 & 100 & 38.9 & 61.1 & 100 & 3.7 & 59.3 & 37 & 100 \\
\hline Wealthy & 13 & 34.8 & 52.2 & 100 & 26.8 & 73.2 & 100 & 0 & 43.8 & 56.3 & 100 \\
\hline \multirow[t]{2}{*}{ Total } & 10.1 & 32.4 & 57.6 & 100 & 30.9 & 69.1 & 100 & 8.75 & 50 & 41.25 & 100 \\
\hline & \multicolumn{4}{|c|}{$\alpha=0.222$, d.f $=6, \chi^{2}=8.23$} & \multicolumn{3}{|c|}{$\begin{array}{l}\alpha=0.422, \text { d.f }=3 \\
\chi^{2}=2.809\end{array}$} & \multicolumn{4}{|c|}{ *Percentages based on multiple responses } \\
\hline
\end{tabular}

a longer-term social protection measure where households received cash/food in return for participating in public works. We also briefly discuss NGO post-disaster interventions. As outlined above, corruption in all these interventions received a 'severe' rating (due to the extreme vulnerability of recipient households).

\subsection{Emergency recovery relief (Tk. 3000-5000 per household)}

After Aila, government stated it would provide Tk. 3-5,000 (US\$ 43-72) to each affected household to meet immediate basic needs (with the amount depending on damage to housing stock). Table 8 shows $97 \%$ of households received this relief (with little variation by wealth quartile). However, Table 8 shows a higher proportion of wealthy households (19.4\%) received more than the stipulated single card (significant at the $99 \%$ level of confidence). This was because household size was the main criteria for allocating cards (with households with six or more members receiving two, twelve or more receiving three) and the average size of households increases through wealth quartiles (from 4.33 to 5.09). However, Table 8 does outline more ultra-poor households ( $8 \%$ ) were forced to pay bribes compared to other wealth categories (significant at the $90 \%$ level of confidence) and paid larger bribes than other categories (again significant at the 90\% level). Thus, survey data suggests the programme did suffer from a low level of corruption. Interestingly, it also reveals a substantial proportion of actors receiving bribes were not local government representatives - such as union parishad members (30\%) and chairmen (10\%) - but middlemen (60\%).

Qualitative methods highlighted how further local officials saw an opportunity from this relief programme: the local land tax collector and chief administrative officer attempted to collect outstanding land taxes from the cash transfer. Whilst a media campaign and interventions by the Member of Parliament and upazilla chairmen stopped this opportunistic taxation, no action was taken against the actors involved. We now turn to corruption in medium-term recovery relief.

\subsection{Medium-term recovery relief (20 $\mathrm{kg}$ rice per household)}

Following the immediate payment of cash transfers to households, government provided $20 \mathrm{kgs}$ of rice per month for each household affected by Aila. Table 9 shows 98\% of households received this recovery relief. Slightly fewer ultra-poor households received rice compared to other quartiles. More importantly, survey data shows $99 \%$ of households received less rice than they were entitled to, with an average loss of 9\% (similar across wealth categories). Again, households were asked which actor was involved in this form of corruption. Survey data shows $74 \%$ of households suffering from this corrupt practice reported union parishad members were responsible (followed by $20 \%$ of households citing union parishad chairmen, and $6 \%$ reporting middlemen).

Qualitative research methods examined whether there were consistent rules and regulations in both emergency and mediumterm recovery relief. Informants stated members and chairmen of union parishad hold high levels of discretionary power to allocate relief cards and distribute goods. For example, one participant explained "nobody received according to their entitlement. . even if the chairman or member said that one card will be given for 6 members of a household, two cards for the members who are more than 6 and 3 cards for 12 members or above, this rule varied from person to person. The cronies of chairmen or members got more benefit from them". But when we compare the amount of rice received across categories on a per adult equivalent basis - ultra-poor households $5.59 \mathrm{kgs}$, poor households $5.21 \mathrm{kgs}$, middle households 4.91 and wealthy households 4.87 - we find wealthier households actually received less than poorer households (an analysis of variance shows this is not statistically significant: $\mathrm{dfs}=3,267 \mathrm{~F}$ ratio $=1.629, F$ test $=0.183$ ). Whilst there may have been cases where union parishad chairmen or members distributed cards as a form of patronage, the greater number of cards received by wealthy households was due mainly to household size, not favouritism. We now turn to the last post-disaster recovery interventions: a public works programme.

Table 8

Emergency recovery relief (Tk. 3000-5000 per household).

\begin{tabular}{|c|c|c|c|c|c|c|c|c|c|c|c|}
\hline \multirow[t]{2}{*}{ Wealth quartile } & \multicolumn{3}{|c|}{$\begin{array}{l}\text { Receipt of emergency } \\
\text { recovery relief }(\%)\end{array}$} & \multicolumn{4}{|c|}{ Number of relief cards received (\%) } & \multicolumn{3}{|c|}{ Forced to pay bribes (\%) } & \multirow{2}{*}{$\begin{array}{l}\text { Average bribe paid } \\
\text { (Taka) }\end{array}$} \\
\hline & Yes & No & Total & One & Two & Three & Total (\%) & Yes & No & Total (\%) & \\
\hline Ultra poor & 95.7 & 4.3 & 100 & 97 & 3 & 0 & 100 & 7.7 & 92.3 & 100 & 1890 \\
\hline Poor & 98.6 & 1.4 & 100 & 89.9 & 10.1 & 0 & 100 & 1.5 & 98.5 & 100 & 1000 \\
\hline Middle & 97.1 & 2.9 & 100 & 98.5 & 1.5 & 0 & 100 & 4.6 & 95.4 & 100 & 350 \\
\hline Wealthy & 97.1 & 2.9 & 100 & 79.1 & 19.4 & 1.5 & 100 & 0 & 100 & 100 & 0 \\
\hline \multirow[t]{2}{*}{ Overall (\%) } & 97.1 & 2.9 & 100 & 91.1 & 8.5 & 0.4 & 100 & 3.4 & 96.6 & 100 & 1277.8 \\
\hline & \multicolumn{3}{|c|}{$\alpha=0.796$, d. $f=3, \chi^{2}=1.023$} & \multicolumn{4}{|c|}{$\alpha=0.002$, d.f $=6, \chi^{2}=20.584$} & \multicolumn{3}{|c|}{$\alpha=0.077$, d. $f=3, \chi^{2}=6.838$} & $\begin{array}{l}\mathrm{dfs}=2,6 \mathrm{~F} \\
\text { ratio }=3.912 \\
F \text { test }=0.08\end{array}$ \\
\hline
\end{tabular}


Table 9

Medium-term recovery relief and cash/food for work.

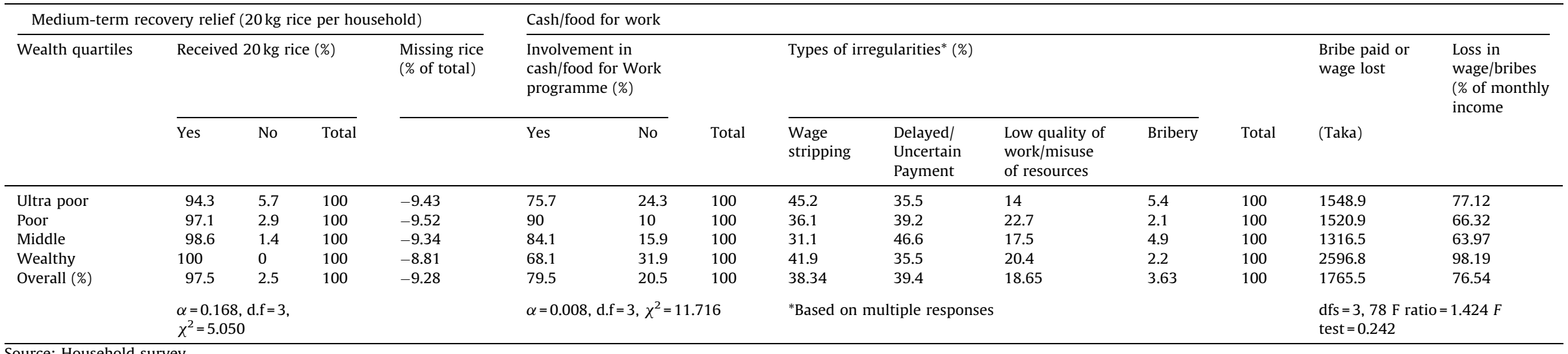

Source: Household survey.

Table 10

Irregularities in NGO relief interventions.

\begin{tabular}{|c|c|c|c|c|c|c|c|c|}
\hline \multirow[t]{2}{*}{ Wealth quartile } & \multicolumn{2}{|c|}{$\begin{array}{l}\text { Irregularities in NGO } \\
\text { relief (\%) }\end{array}$} & \multirow[t]{2}{*}{ Total } & \multicolumn{4}{|c|}{ Types of irregularities (\%)* } & \multirow[t]{2}{*}{ Total } \\
\hline & Yes & No & & Bribery/stripping & Nepotism & Influence peddling & Low quality goods & \\
\hline Ultra poor & 47.8 & 52.2 & 100 & 24.1 & 19 & 46.6 & 10.3 & 100 \\
\hline Poor & 58.6 & 41.4 & 100 & 15.4 & 29.5 & 35.9 & 19.2 & 100 \\
\hline Middle & 69.6 & 30.4 & 100 & 19.8 & 32.7 & 34.7 & 12.9 & 100 \\
\hline Wealthy & 79.7 & 20.3 & 100 & 17.9 & 35.8 & 32.1 & 14.2 & 100 \\
\hline \multirow[t]{2}{*}{ Overall } & 63.9 & 36.1 & 100 & 18.95 & 30.61 & 36.15 & 14.29 & 100 \\
\hline & \multicolumn{3}{|c|}{$\alpha=0.001$, d.f $=3, \chi^{2}=17.026$} & \multicolumn{4}{|c|}{ *Based on multiple responses } & \\
\hline
\end{tabular}

Source: Household survey. 
Table 11

Nature and extent of corruption in pre- and post-disaster interventions.

\begin{tabular}{|c|c|c|c|c|c|c|c|c|}
\hline \multirow[t]{2}{*}{ Stage } & \multirow[t]{2}{*}{ Intervention types } & \multirow{2}{*}{$\begin{array}{l}\text { Type of evidence: } \\
\text { hearsay/own } \\
\text { experience }\end{array}$} & \multicolumn{6}{|c|}{ Nature and extent of corruption } \\
\hline & & & $\begin{array}{l}\text { Severity of } \\
\text { corrupt } \\
\text { practice: } \\
\text { mild/severe }\end{array}$ & $\begin{array}{l}\text { Incidence of } \\
\text { corruption }^{\mathrm{a}}\end{array}$ & Type/s of corruption & $\begin{array}{l}\text { Bribery paid or } \\
\text { relief received } \\
\text { (taka or \%) }\end{array}$ & Primary actor (s) & Primary victim \\
\hline \multirow[t]{3}{*}{$\begin{array}{l}\text { Pre-disaster } \\
\text { interventions }\end{array}$} & Warning message & Own experience & Mild & Very high $(83 \%)$ & Negligence to provide services & NA & $\begin{array}{l}\text { Government Officer, } \\
\text { Public Representative }\end{array}$ & Ultra poor \\
\hline & $\begin{array}{l}\text { Disaster preparedness } \\
\text { training }\end{array}$ & Own experience & Mild & Medium (31\%) & Nepotism/favouritism/patronage & NA & Government officer & Middle and poor \\
\hline & $\begin{array}{l}\text { Access to cyclone } \\
\text { shelter }\end{array}$ & Own experience & Mild & Low (9\%) & Influence peddling & NA & Social elite & All \\
\hline \multirow[t]{5}{*}{$\begin{array}{l}\text { Post-disaster } \\
\text { interventions }\end{array}$} & $\begin{array}{l}\text { Emergency recovery } \\
\text { relief }\end{array}$ & Own experience & Severe & $\begin{array}{l}\text { Low (exclusion - 3\%; } \\
\text { bribery - 3\%) }\end{array}$ & $\begin{array}{l}\text { Negligence to provide services, } \\
\text { bribery/stripping }\end{array}$ & Tk. 1277 & $\begin{array}{l}\text { Exclusion: members and } \\
\text { chairman of union parishad } \\
\text { bribes: middlemen }\end{array}$ & Ultra poor \\
\hline & $\begin{array}{l}\text { Mid-term recovery } \\
\text { relief }\end{array}$ & Own experience & Severe & $\begin{array}{l}\text { Very high (exclusion - 3\%; } \\
\text { stripping - 99\%) }\end{array}$ & $\begin{array}{l}\text { Bribery/stripping, negligence } \\
\text { to provide services }\end{array}$ & $9.28 \%$ & $\begin{array}{l}\text { Members and chairman } \\
\text { of union parishad }\end{array}$ & All \\
\hline & Cash/food for work & Own experience & Severe & $\operatorname{High}(68 \%)$ & $\begin{array}{l}\text { Bribery/stripping, misuse of } \\
\text { resources, fraud }\end{array}$ & Tk. 1765 & $\begin{array}{l}\text { Middlemen; member and } \\
\text { chairman of union parishad }\end{array}$ & Wealthy \\
\hline & $\begin{array}{l}\text { Embankment } \\
\text { reconstruction }\end{array}$ & Hearsay & Severe & Very high $(94 \%)$ & $\begin{array}{l}\text { Misuse of resources, bribery stripping, } \\
\text { procurement irregularities, negligence } \\
\text { to provide services }\end{array}$ & $\begin{array}{l}\text { Estimated by key } \\
\text { informant to be } \\
40-55 \% \text { of total } \\
\text { project }\end{array}$ & $\begin{array}{l}\text { Syndicate of ruling } \\
\text { party activists }\end{array}$ & All \\
\hline & NGO interventions & Own experience & Severe & High (64\%) & $\begin{array}{l}\text { Influence peddling, nepotism/ } \\
\text { favouritism/patronage, } \\
\text { bribery/stripping }\end{array}$ & Tk. 627 & $\begin{array}{l}\text { Middlemen, NGO officers, } \\
\text { member and chairman } \\
\text { of union parishad }\end{array}$ & Wealthy \\
\hline
\end{tabular}

${ }^{a}$ incidence of corruption: low $=<25 \%$; medium $=26-50 \%$ incidence of corruption; high $=51-75 \%$ incidence of corruption; very high $=>75 \%$ 


\subsection{Cash/food for work interventions}

As land in the upazilla was flooded with saline water, reduced labour demand forced many mobile residents to migrate to find work. To tackle this situation, government launched a cash/foodfor-work scheme. Overall, $80 \%$ of households participated in the scheme at some stage, with a greater proportion of poor and middle households than ultra-poor and wealthy (statistically significant at the 99\% confidence level, see Table 9). However, the scheme was plagued by discrepancies. Overall, $68 \%$ of respondents reported irregularities, particularly with wage stripping and delayed or uncertain payment (see Table 9).

Qualitative methods examined these irregularities. One focus group complained the enrolment list for the scheme, created on the first day, was not updated as the number of workers decreased, that chairmen of the union parishad added false names, and that labourers did not receive a fixed amount of rice. Table 9 shows the average wages lost or bribes paid by households in this scheme came to Tk. 1766 (US\$ 25). Looking into wealth quartiles, wealthy households lost more wages (both in absolute terms and as a proportion of monthly income) compared to other groups.

A further issue highlighted by focus groups was the low quality of work conducted on the scheme. For example, one participant reported: "the work was awarded to inexperienced sub-contractors. They do not know how to reconstruct roads, dams or embankments especially in the coastal belt. After finishing some work, the roads/ embankments were just washed away by a tidal surge. They used this as an excuse not to pay wages to workers".

Overall, recovery relief after Aila suffered from varied levels of corruption: low levels of bribery in the Tk. 5000 programme; very high levels of asset stripping by union parishad chairmen and members in the food distribution programme; and high levels of wage stripping and delayed/uncertain payment, as well as other irregularities, in the public works programme. We now turn to corruption in one post-disaster rehabilitation intervention.

\section{Rehabilitation intervention}

Here we consider one major government programme: embankment reconstruction. In July 2009, the Ministry of Food and Disaster Management allocated Tk. 1150 million (US\$16.4 million) to the Water Development Board for the repair of vital embankments damaged or destroyed in Aila. This section examines people's perceptions about government's steps to reconstruct embankments, and tries to identify the extent of corruption in this intervention. As highlighted above, because this data is not based on direct experience but on hearsay we need to be cautious about these findings.

The first point to note is the Water Development Board failed to commence embankment reconstruction promptly. For example, on 7th April 2010, the Prime Minister criticised officials for this failure (The Daily Star, 2010). The Prime Minister's dissatisfaction is reflected in respondents' perceptions: $82 \%$ did not feel necessary action had been taken to reconstruct embankments after Aila, and almost $60 \%$ were fully dissatisfied with the government's response. Two focus groups stated a clear preference the army should have been deployed from the start for this vital task.

Survey data shows $94 \%$ of respondents reported irregularities in the embankment reconstruction process including the misuse of resources, low quality of work and corrupt tendering. The political mechanisms at work here were hard to untangle. It was reported the main contractor was prevented from working due to pressure from a cadre within the ruling political party. Moreover, it was stated the contractor was forced to sub-contract to this cadre: in other words, it was alleged local government representatives, party activists and wealthy households, under the protection of the
Member of Parliament, formed a syndicate which was subcontracted to complete the work. Due to time pressure, the research could not pursue this line of enquiry. We now turn to the final post-disaster intervention: NGO programmes.

\subsection{NGO post-disaster interventions}

The survey found $98 \%$ of households received some kind of relief (in cash or in kind) from NGOs (ranging from $100 \%$ of ultrapoor households to $94.2 \%$ of wealthy households, significant at the $95 \%$ level). Overall $64 \%$ found irregularities in NGO operations, with, interestingly, wealthy households (80\%) reporting the greatest incidence of corrupt practices (significant at the $99 \%$ level with one non response excluded). Table 10 also shows influence peddling by representatives and nepotism were the most common irregularity, followed by bribery and asset stripping. In addition, the quality and appropriateness of goods distributed by NGOs was questioned. For example, one participant in a FGD stated "most often the relief goods were not suitable for Bangladesh considering the socio-economic condition. For example, they gave mosquito nets which are washable only in a machine, and they gave tents which are not suitable for high temperatures so get damaged within a few months due to the hot weather and rain."

The amount paid in bribes by twenty three households varied across the poverty/wealth categories. On average, ultra-poor households paid Tk. 325, poor households Tk. 330, middle households Tk. 438 and wealthy households Tk. 1040 ( dfs =3, $19 \mathrm{~F}$ ratio $=1.62 \mathrm{~F}$ test $=0.218$ ). Over half these households paid this bribe to a middleman, with the remaining households either paying an NGO officer or a member/chairman of the union parishad.

\section{Discussion}

Almost every household surveyed reported losses from corrupt practices before or after Aila. The key findings are summarised in Table 11. Overall, whilst poorer households were affected more by 'mild' corruption in pre-disaster interventions, the incidence of corruption in these schemes was lower than in post-disaster operations, especially food aid distributions and public works. Interestingly, wealthy households were affected more by the 'severe' corruption after Aila, especially within public works and non-governmental interventions. These findings contrast with Iftekharuzzaman's (2009) national findings where poorer households bore the brunt of corrupt practices (due to the higher proportion of income spent). Our findings also highlight different types of corruption before and after Aila: negligence to provide services and nepotism were most common within pre-disaster interventions. In post-disaster interventions, wage/asset stripping, bribery and the misuse of resources were most prevalent.

\section{Conclusion}

Broadening out from this particular case, these findings may hold relevance for agencies involved in adaptation. Bangladesh is frequently applauded for efforts to mainstream adaptation into policy (such as through integrating climate concerns into the Poverty Reduction Strategy Paper) and creating the necessary funding mechanisms to absorb large climate resource flows (such as the National Climate Change Trust Fund and Climate Resilience Fund). Vibrant civil society organisations in Bangladesh have supported autonomous adaptation initiatives such as communitybased adaptation (for example, see Huq and Reid, 2007). However, our findings suggest without increasing integrity, hard-won funding will not increase the resilience of poor households and communities to the extent it might. 
This is because there is considerable overlap between the eight interventions assessed here and the adaptation pillars highlighted by the Climate Change Strategy and Action Plan, and early projects financed by Climate Change Trust Fund and Climate Resilience Fund. For example, the Climate Change Strategy and Action Plan covers a ten-year period (2009-2018) implemented in two phases: 2009-2013 and 2014-2018 (MoEF, 2009). In the first phase government highlighted six pillars, the first three of which resonate with the cyclone preparedness and relief efforts evaluated in this article: food security, social protection and health; comprehensive disaster management; infrastructure; research and knowledge management; mitigation and low carbon development; and capacity building \& institutional strengthening (MoEF, 2009:27-32). Moreover, the funding allocation under the Climate Change Trust Fund shows a distinct focus on disaster preparedness and relief efforts. Of the US\$95.36 million allocated to projects as of December 2011, over US\$56 million was directed to projects under the first three pillars of the Strategy and Action Plan. Indeed, the first approved project was US\$25 million for constructing cyclone shelters. The budget allocations under the Climate Change Trust Fund also show the Water Development Board as the ministry receiving the greatest proportion of funds, the same body which $94 \%$ of respondents alleged was involved in corrupt practices during embankment reconstruction. Turning to the Climate Resilience Fund, some initial projects also reflect similar disaster preparedness priorities, including the construction of cyclone shelters.

The precise anti-corruption measures that might work within adaptation projects are not easy to discern. For example, the literature on corruption outlines generic approaches such as extra payments to civil servants to increase honesty (so-called efficiency wages), increased competition between public officials, increased monitoring and sustained public awareness campaigns (see Bardhan, 1997). Olken (2007) usefully contrasts such traditional, top-down instruments with grassroots, local-level monitoring (for example, the use of social audit tools, or supporting transparent and competitive procurement systems through engaging civil society in tendering and selection processes). In the Indonesian case Olken (2007) examined, the conventional threat of a topdown audit reduced corruption to a greater extent than bottom-up local-level monitoring. It may well be the case that experimenting with specific anti-corruption measures in Bangladesh could shed light on effective remedies. Whilst only a first step, such analysis could assist government, non-governmental organisations and development partners in formulating a range of innovative measures during implementation.

\section{Acknowledgements}

The authors would like to convey their deepest sense of gratitude to respondents of the survey, participants of focus group discussion, and key informants for sharing their experiences and insightful observations on pre- and post-disaster interventions. The authors would also like to thank the field research team Dhiman Mondol, Parthajit Roy, Utpal Kumar Das, Shaikh Shahidul Islam, Shuvro Chandan Mahali, S.M. Khaledur Rahman, Md. Nazrul Islam and Tanmay Mondal - for their hard work during data collection and entry.

In addition, the authors thank Nihar Ronjon Roy and Bishawjit Mallick for their help in understanding the local socio-political context before and after Aila, as well as the Coastal Research Foundation (CRF) for being a partner and providing support during the field survey. The authors would like to thank the Flemish Interuniversity Council (VLIR) for the scholarship that enabled this study. Additional fieldwork finance was received from the Institute of Development Policy and Management (IOB), Antwerp, Belgium.
Comments from reviewers and editors are gratefully acknowledged. Finally, this publication is an independent and collaborative effort between both authors. It does not represent the views of TI Bangladesh, IOB or the Department of Geography and Geology, University of Copenhagen.

\section{References}

Adger, W.N., Brooks, N., Bentham, G., Agnew, M., Eriksen, S., 2004. New indicators of vulnerability and adaptive capacity. In: Technical Report 7, Tyndall Centre for Climate Change Research, University of East Anglia, Norwich.

Aidt, T., 2009. Corruption, institutions, and economic development'. Oxford Review of Economic Policy 25 (2), 271-291.

Ansoms, A., McKay, A., 2010. A quantitative analysis of poverty and livelihood profiles: The case of rural Rwanda. Food Policy 35, 584-598.

Bardhan, P., 1997. Corruption and development: a review of issues. Journal of Economic Literature 35, 1320-1346.

Barr, C., Dermawan, A., Purnomo, H., Komarudin, H., 2010. Financial governance and Indonesia's reforestation fund during the Soeharto and post-Soeharto periods, 1989-2009: a political economic analysis of lessons for REDD+. In: Occasional Paper 52, CIFOR, Bogor, Indonesia.

Carney, D. (Ed.), 1999. Sustainable Rural Livelihoods: What Contribution can we make? DfID, London.

Chambers, R., Conway, G.R., 1992. Sustainable rural livelihoods: practical concepts for the 21st century. In: Discussion Paper 296, Institute of Development Studies, Brighton, UK.

Dasgupta, A., Baschierri, A., 2010. Vulnerability to climate change in rural ghana: mainstreaming climate change in poverty reduction strategies. Journal of International Development 22, 803-820.

Duncan, N., Dutta, I., 2006. Guest editors' introduction. World Development 34 (2), 324-327.

Ebeling, J., Yasue, M., 2009. The effectiveness of market-based conservation in the tropics: Forest certification in Ecuador and Bolivia. Journal of Environmental Management 90, 1145-1153.

Filmer, D., Pritchett, L., 2001. Estimating wealth effects without expenditure data or tears: an application to educational enrolments in states of India. Demography 38 (1), 115-132.

Global Leadership for Climate Action (GLCA), 2009. Facilitating an International Agreement on climate change: adaptation to climate change, June 2009. www.globalclimateaction.org

Green, J., 2008. Delegation and accountability in the clean development mechanism: the new authority of non-state actors. Journal of International Law and International Relations 4 (2), 21-55.

Haque, M.E., Kneller, R., 2009. Corruption clubs: endogenous thresholds in corruption and development. Economic Governance 10, 345-373.

Harttgen,K., Klasen,K., 2012. A household-based human development index. world development, 40 (5), 878-899.

Hulme, D., McKay, A., 2005. Identifying and measuring chronic poverty: beyond monetary measures. In: The Many Dimensions of Poverty Conference, Brasilia, Brazil, June 2005

Huq, S., Reid, H., 2007. Community-based adaptation: a vital approach to the threat climate change poses to the poor. In: IIED, Briefing, International Institute for Environment and Development, London.

Iftekharuzzaman, Tanvir, M. 2008. Country Report - Corruption in Water Sector in Bangladesh. In: Transparency International, 2008. Global Corruption Report 2008. Transparency International, Cambridge University Press, pp. 181 186.

Iftekharuzzaman, 2009. Corruption \& human insecurity in Bangladesh. In: Paper presented at the NTS-Asia Annual Convention, Singapore, November, 3-4, 2009.

Intergovernmental Panel on Climate Change (IPCC), IPCC Working Group II, 2001. Climate Change 2001: Impacts Adaptation and Vulnerability. Cambridge University Press, Cambridge, UK.

Intergovernmental Panel on Climate Change (IPCC), 2007. Climate change 2007: impacts, adaptation and vulnerability. In: Contribution of Working Group II to the Fourth Assessment Report of the Intergovernmental Panel on Climate Change, Cambridge University Press, Cambridge, UK.

Karklins, R., 2002. Capitalism, corruption, and something else - typology of postcommunist corruption. Problem of Post Communism 49 (4), 22-32.

Leff, N., 1964. Economic development through bureaucratic corruption. American Behavioral Scientist 8 (3), 8-14.

Marivoet, W., Keje, H., 2011. Approfondir le profilage géographique de la pauvreté en RDC: l'introduction d'indices composites sur base des avoirs. In: Discussion Paper 2011.1, Institute of Development Policy and Management (IOB), University of Antwerp, Belgium.

Martinez, G., Bastemeijer, T., 2011. Climate change adaptation and water integrity: a global challenge to address local realities. In: Transparency International, 2011. Global Corruption Report: Climate Change. Earthscan, London.

Ministry of Environment and Forests (MoEF), 2005. National Adaptation Program of Action, Government of Bangladesh, Dhaka, http://www.moef.gov.bd/

Ministry of Environment and Forests (MoEF), 2009. Bangladesh Climate Change Strategy and Action Plan 2009. Government of Bangladesh, Dhaka, http:// www.moef.gov.bd/. 
Moser, C., Felton, A., 2007. The construction of an asset index: measuring asset accumulation in Ecuador. In: CPRC Working Paper 87, Chronic Poverty Research Centre, University of Manchester, UK.

Myrdal, G., 1968. Asian Drama: An Enquiry into the Poverty of Nations. The Twentieth Century Fund, New York.

Olken, B., 2007. Monitoring corruption: evidence from a field experiment in Indonesia. Journal of Political Economy 115 (2), 200-249.

Ostrom, E., 2010. Polycentric systems for coping with collective action and global environmental change. Global Environmental Change 20 (4), 550-557.

Pielke, R., Prins, G., Rayner, S., Sarewitz, D., 2007. Lifting the taboo on adaptation. Nature 445, 597-598.

Qizilbash, M., 2001. Corruption and human development. Oxford Development Studies 29 (3), 265-278.

Reinikka, R., Svensson, J., 2006. Using micro-surveys to measure and explain corruption. World Development 34 (2), 359-370.

Rygel, L., O’Sullivan, D., Yarnall, B., 2006. A method for constructing a social vulnerability index: an application to hurricane storm surges in a developed country. Mitigation and Adaptation Strategies for Global Change 11, 741764.
Tabachnick, B.G., Fidell, L.S., 2007. Using Multivariate Statistics. Pearson, Boston, US. Tanvir, M., 2006. Corruption Database 2005. Transparency International Bangladesh, July 5, 2006, Dhaka, Bangladesh.

The Daily Star, 2010. PM Lambasts Tardy Embankment Repair. April 8, 2010, Dhaka. Transparency International Bangladesh (TIB), 2008. National Household Survey 2007 on Corruption in Bangladesh, June 2008. Dhaka.

Transparency International Bangladesh (TIB), 2010. Corruption in the Service Sectors: National Household Survey 2010. December 2010, Dhaka.

Transparency International, 2009. The Anti-Corruption Plain Language Guide. July 2009, Berlin, Germany.

Vogt, J., Mallick, B., Mahboob, A.S., 2009. Social Supremacy and location of cyclone centre: a determinant of social vulnerability analysis in a Coastal Union of Bangladesh. In: Conference Proceedings: Water and Flood Management 2009, Dhaka, pp. 415-423.

World Bank, 2000. Corruption in Bangladesh: Costs and Cures. World Bank, April 7. Dhaka.

Zaman, I. and Khuda, M., 2011. Climate Change and Corruption Leave the World's Largest Mangrove Forest in Peril. In Transparency International, 2011. Global Corruption Report: Climate Change. Earthscan, London. 